\title{
DEVICES OF RPC “TENZOR" FOR INVESTIGATION OF PHYSICAL ENVIRONMENTAL FACTORS
}

\section{ПРИЛАДИ НВФ “ТЕНЗОР” ДЛЯ ДОСЛІДЖЕННЯ ФІЗИЧНИХ ФАКТОРІВ ЗОВНІШНЬОГО СЕРЕДОВИЩА}

\author{
B.G. Shabashkevych, candidate of technical sciences, director of RPC "Tenzor", Chernivtsi \\ Yu.G. Dobrovolskyi, doctor of technical sciences, deputy director of RPC "Tenzor", Chernivtsi
}

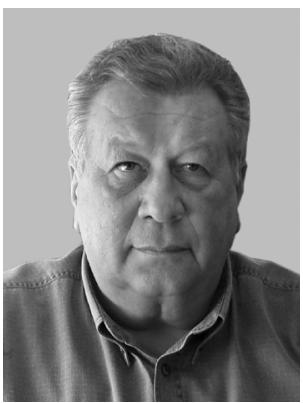

B.G. Shabashkevych

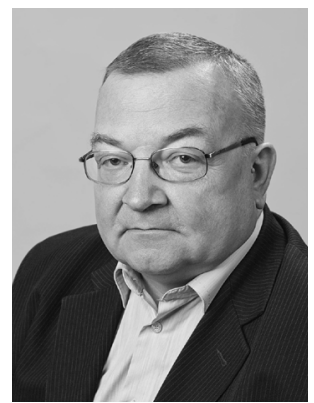

Yu.G. Dobrovolskyi
The results of multi-year research of Research \& Production Company (RPC) "Tenzor" on creating measuring instruments to perform measurements of radiometric and photometric characteristics of optical radiation in the ultraviolet, visible and infrared regions of the spectrum, measurements of microclimate parameters, measurements of noise and vibration metrology equipment are presented. The issue on measuring the luminance of LED sources using a photometer Ecotenzor-03, illuminance measurement range of which is from $10^{-2}$ to $2 \times 10^{5}$ lux, is considered in detail.

Keywords: photometer, ripple coefficient, measurement, radiometer, lightning engineering.

Наведено результати багаторічних досліджень Науково-виробничої фірми “Тензор” зі створення засобів вимірювальної техніки для вимірювання радіометричних та фотометричних характеристик оптичного випромінювання в ультрафіолетовій, видимій та інфрачервоній областях спектра, вимірювання параметрів мікроклімату, вимірювання шуму та вібрації, а також їх метрологічного забезпечення. Детально розлянуто питання вимірювання яскравості світлодіодних джерел із використанням фотометра Екотензор-03, діапазон вимірювань освітленості якого становить від $10^{-2}$ до $2 \times 10^{5}$ люкс.

Ключові слова: фотометр, коефіцієнт пульсації, вимірювання, радіометр, світлотехніка.

\section{Problem statement}

Nowadays the actual task is the control of physical factors that affect people in particular and the en- vironment in general. To ensure such control measuring equipment the RPC "Tenzor" for 26 years develops and manufactures measuring devices to measure physical environmental factors, including radiometric and photometric characteristics of optical radiation in the ultraviolet, visible and infrared regions of the spectrum, measuring microclimate parameters and metrological equipment.

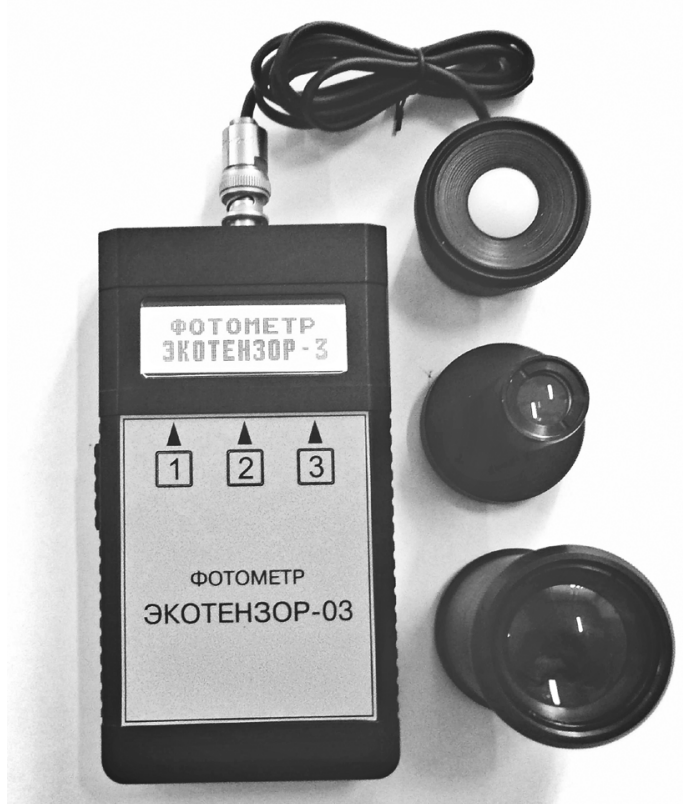

Fig.1. Photometer Ecotenzor-03

Goal of the article

To highlight the experience and the results of development of measuring instruments created by RPC "Tenzor". 


\section{Results}

By working closely with the NSC "Institute of Metrology", especially in the metrological direction, our company developed a number of devices, installations and stands, which control photometric and energy parameters of optical radiation in the range of $0.2-25 \mathrm{mi}-$ crons. In particular, there are luxmeters and photometers, radiometers of ultraviolet and heat radiation.

To measure the illumination created by natural and artificial sources of light, brightness of self-luminous and non self-luminous objects as well as the coefficient of ripple light sources, we produced the photometer (digital luxmeter-brightmeter-pulsmeter) Ecotenzor-03 (Fig. 1). Its illumination measuring range is $10^{-2}-2 \cdot 10^{5}$ lux and brightness is $1-2 \cdot 10^{5} \mathrm{~cd} / \mathrm{m}^{2}$, the limits of permissible basic relative error of illumination measurement are $\pm 5 \%$ and brightness is $\pm 7 \%[1,2]$. The device is characterized by achieved high accuracy, including the use of specialized photodiodes and light filters, in accordance with the Standards of Ukraine of Ministry of Industrial Policy $29.200-024$ to the $1^{\text {st }} \& 2^{\text {nd }}$ class converters with the following accuracy:

- in the wavelength range from 0.4 microns to 0.75 microns $\left(\left|\Delta_{\text {max }}\right|\right)$ not more than $3 \%$ for the $1^{\text {st }}$ class and $5 \%$ for the $2^{\text {nd }}$ class;

- in the wavelength range from 0.3 microns to 0.4 microns $\left(\alpha_{u v}\right)$ not more than $0.5 \%$ for the $1^{\text {st }}$ class and $1 \%$ for the $2^{\text {nd }}$ class;

- in the wavelength range from 0.75 microns to 1.2 microns $\left(\alpha_{\mathrm{ir}}\right)$ not more than $0.5 \%$ for the $1^{\text {st }}$ class and $1 \%$ for the $2^{\text {nd }}$ class.

Measurement range ripple coefficient is 1-100\% in the frequency range from 10 to $300 \mathrm{~Hz}$. The limits of main permissible relative error of measuring the ripple coefficient are $\pm 10 \%$.

One of the main problems in measuring environmental parameters of lighting is the problem of correct range ripple coefficient $R_{\mathrm{c}}$, which is one of the main criteria for evaluating the relative depth of illumination fluctuations [3]. In our case, the ripple coefficient is defined as the ratio of maximum to half the sum $\left(E_{\max }\right)$ and minimum $\left(E_{\min }\right)$ values of light, measured over a discrete time interval to the same value on middling measured light $\left(E_{\text {mid }}\right)$.

$$
R_{\mathrm{c}}=\frac{E_{\max }-E_{\min }}{2 E_{\text {mid }}} \cdot 100 \% .
$$

The middling value is the sum of all measured values of light divided into the number of measurements. In this case, software allows setting time intervals digitization measurements, number of measurements per second, the total time of measurement, and setting thresholds of illumination to be set for the removal of abnormal quantities of sample illumination, which are not repeated within the duration of the measurement. In addition, the increased frequency ripple factor measurements accurately measure the middling value of light, which in turn improves the measuring accuracy. Frequency range of measurements is up to $300 \mathrm{kHz}$.
Coefficient of authenticity in the developed device is similar to authenticity of photometer TEC 0693 , as all of the optical and photometric part of the device is made under the scheme of its prototype TEC 0693. So, its coefficient of authenticity is close to 1 . This fact is very significant when measuring characteristics of white LEDs, since these light sources in their light characteristics are different from the type A, and virtually all existing luxmeters are calibrated on such sources [4]. Thus, developed photometer "Ecotenzor-03" is the most suitable for measuring light waves generated by LED light sources.

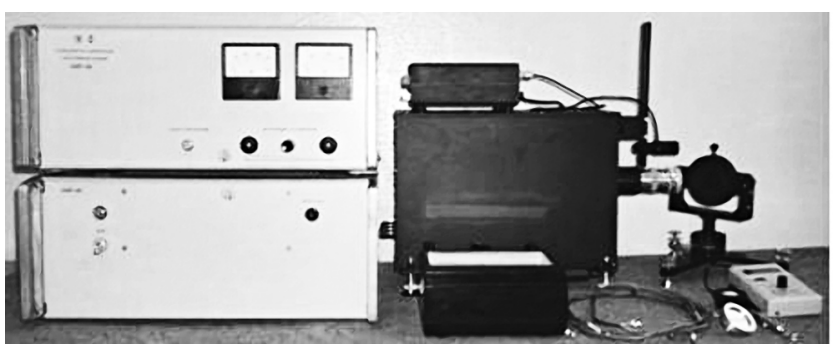

Fig. 2. Installation ИДНМ4.023.000.000

To measure low levels of illumination (from $10^{-5}$ lux) the luxmeter-brighmeter Tenzor-25 is created [2].

To measure the intensity of light we created the devices Tenzor-26 with measuring range $0.1-2 \cdot 10^{5} \mathrm{~cd}$ at acceptable limits of basic relative measurement error $\pm 5 \%$ and Tenzor-26M for measuring the intensity of external light devices of road vehicles in accordance with State Standard of Ukraine 3649-97 [2].

Photometer Tenzor-27 provides the measurement of brightness in the range of $10^{-3}-2 \cdot 10^{5} \mathrm{~cd} / \mathrm{m}^{2}$ [2].

To control a specific coefficient of light intensity $(K)$ materials with optical effect according to State Standard of Ukraine 2586-94 and 4100-2002 a special installation ИДНМ 4.023.000.000 is developed (Fig. 2) [2]. It consists of illuminator, photometer Ekotenzor-03 luxmeter with low levels of illumination (measuring range of illumination is from $10^{-5}$ lux to $2 \cdot 10^{3}$ lux), bracket for bonding photometric head of luxmeter on the illuminator, rotating table, light power supply, ammeter, alignment mirror and a flashlight. By moving photometric head of luxmeter in a bracket, the measuring of $K$ sample is provided with the observation angles $(\alpha) 0^{\circ} 12^{\prime}, 0^{\circ} 20^{\prime}$ и $1^{\circ} 30^{\prime}$. Range luxmeter data show low levels of illumination from $1 \cdot 10^{-5}$ to $2 \cdot 10^{3}$ lux. The limits of basic relative permissible error of luxmeter are not more than $\pm 10 \%$. The limits of basic relative permissible error of measuring the specific coefficient of light intensity are $\pm 15 \%$.

Measuring of transmission coefficients and reflection window glass in the visible range provides Tenzor-21 [2] which carries out measurements of these coefficients with the limit of absolute error not more than $1 \%$ and $2 \%$ respectively.

To make similar measurements in the ultraviolet and infrared ranges of the spectrum the appropriate Tenzor-22 [2] and Tenzor-21 IR [2] are produced.

The control of energy light in the ultraviolet spectral range of $0.2-0.4$ microns posed by mercury, deuterium 
and arc sources provides UV dosimeter-radiometer Tenzor-71 [2]. The device provides measurement of energy illumination separately in each of the UV ranges A, B, $\mathrm{C}$ by one device in the range of $10^{-4}-2 \cdot 10^{2} \mathrm{~W} / \mathrm{m}^{2}$ with the limit of permissible basic relative measurement error of $\pm 10 \%$. Working as UV radiation dosimeter the device provides the following spectral measurement ranges: $280-400 \mathrm{~nm}$ as erythemal and $200-400 \mathrm{~nm}$ as bactericidal. Measurement range of energy dose is $10^{7} \mathrm{~J} / \mathrm{m}^{2}$. The range of setting time of dose accumulation is from $1 \mathrm{sec}$. up to 100 hours. Limits of basic relative permissible error of luxmeter are not more than $\pm 15 \%$. The device allows you correctly to measure the light energy and dose posed by any source of ultraviolet radiation.

To measure energy illumination (intensity) of glow mercury germicidal lamps with working wavelength of $254 \mathrm{~nm}$ at the UV dosimeter-radiometer Tenzor-71 we created an appropriate tester [2]. Measurement range of device energy illumination at a wavelength of $254 \pm 2$ $\mathrm{nm}$ is $0.5-1.5 \mathrm{~W} / \mathrm{m}^{2}\left(50-150 \mathrm{~mW} / \mathrm{cm}^{2}\right)$ at basic relative error limits of $\pm 10 \%$.

For control of microclimate parameters we created the corresponding meter Ecotenzor-MC which includes a probe for measuring temperature, air humidity, pressure, air velocity, index of heat load environment and the probe to measure the intensity of thermal radiation [2].

To measure the energy illumination from 10 to $2 \cdot 10^{4} \mathrm{~W} / \mathrm{m}^{2}$ in the range of $0.2-25$ microns a modified digital version of radiometer РАT-2П (Fig. 3) is created [2]. The limits of basic relative permissible error of measurement are $\pm 6 \%$.

Measuring blocks of mentioned devices are made in the same type of portable frames with indication based on liquid crystal displays, combined power (from the net and battery) having low power consumption.

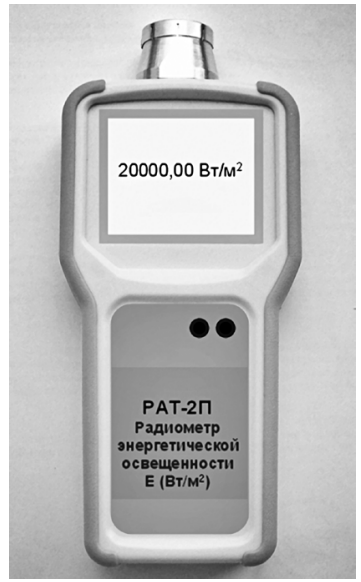

Fig. 3. РАТ-2П

For certification, calibration, primary and periodic testing of devices produced by Research and Production Company "Tenzor" in cooperation with Chernivtsi Center of Standardization, Metrology and Certification and NSC "Institute of Metrology" (Kharkiv) a complex of installations is created:

- installation for testing means of measuring energy illumination ИДНМ4.009.00.00 which is completed by standard means of measurement like type $\mathrm{HC}$ (Hollow Converter) with the basic relative error of measurement $\pm 1,0 \%$;

- device for measuring photometric parameters of optoelectronic devices ИДНМ4.003.00.00 [5], completed by self produced standard photometric measuring heads with the basic relative error of measurement $\pm 1,5 \%$;

- stand to create a stable flow of radiation in measuring energetic characteristics and sensitivity nonlinearity of electronic \& optical devices ИДНМ 4.004.00.00 [5]; the instability of created radiation flow is $\pm 0,5 \%$;

- device for measuring the coefficient of ripple sources of optical radiation ИДНМ4.024.00.00 [2];

- installation for forming flows of radiation in the UV range (UV illuminator range) ИДНМ4.020.00.00 [6];

- automated measuring spectral range (upgraded Complex Spectral Calculating, Universal - CSCU-23), completed with self produced standard radiometric heads with the basic relative error of measurement $\pm 6,0 \%$ [2]

\section{Conclusions}

To control physical factors affecting people and environment, the measuring equipment to measure radiometric and photometric characteristics of optical radiation in the ultraviolet, visible and infrared regions of the spectrum, measuring microclimate parameters and metrological equipment is developed.

\section{References}

1. Shabashkevich B.G., Dobrovolskiy Yu.G., Mamaev S.V., Kushyn V.V. Sovremennyi tsyfrovoi pribor dlya izmereniya harakteristik svetovoi sredy // Svitlotehnika ta elektroenergetika. 2013. № 1. S. 44-49.

2. Elektronnyi resurs. URL: http://tenzor.ua

3. Shabashkevich B. G., Dobrovolskyi Yu.G. Fotometry NPF "Tenzor" dlya izmereniya parametrov svetovoi sredy na sootvetstvie novoi redaktsyi DBN V.2.5-28:2006 // Promyslova elektroenergetyka ta elektrotehnika. 2015. № 4. S. 6-9.

4. Diduh N.I., Miheyenko L.A., Svyeshnikov V.S. Radiometriya i metrolohiya svitlodiodiv // Visnyk NTUU "KPI". Seriya Pryladobuduvannya. 2010. Vyp. 40. S. 46-54.

5. Shabashkevych B.G., Dobrovolskyi Yu.G., Yuriyev V.H. Metrologichnyy kompleks dlya perevirky i graduyuvannya optoelektronnyh pryladiv u vydymomu diapazoni spektru // Metrologiya ta prylady. № 3. 2015. S. 18-23.

6. Butenko V.K., Dobrovolskyi Yu.G., Shabashkevych B. G., Yuriyev V. G. Osvitlyuvach dlya kalibruvannya UF-radiometriv // Ukrains'kyi metrologichnyi zhurnal. 2008. № 1. S. 29-33.

Статтю рекомендовано до публікації доктором технічних наук, провідним науковим співробітником О.Д. Купко.

The article is recommended for publication by O.D. Kupko, Doctor of Technical Sciences, Leading Researcher. 